\title{
The Use of Water in Agriculture in Mexico and Its Sustainable Management: A Bibliometric Review
}

\author{
Claudia A. Ochoa-Noriega ${ }^{1}$, José A. Aznar-Sánchez ${ }^{1, * \mathbb{C}}$, Juan F. Velasco-Muñoz ${ }^{1}{ }^{\mathbb{C}}$ and \\ Alejandro Álvarez-Bejar ${ }^{2}$ \\ 1 Department of Economy and Business, Research Centre CIAIMBITAL and CAESCG, University of Almería, \\ 04120 Almería, Spain; claudia08a@hotmail.com (C.A.O.-N.); jfvelasco@ual.es (J.F.V.-M.) \\ 2 Department of Economy, National Autonomous University of México, Mexico D.F. 04510, Mexico; \\ abejar@unam.mx \\ * Correspondence: jaznar@ual.es
}

Received: 20 November 2020; Accepted: 9 December 2020; Published: 12 December 2020

\begin{abstract}
The development of agricultural activity in Mexico is generating environmental externalities that could compromise its future. One of the principal challenges facing the Mexican agricultural sector is to find a way to continue growing without jeopardising the availability and quality of its water resources. The objective of this article is to analyse the dynamics of the research on the use of water in agriculture in Mexico and its sustainable management. To do this, a review and a bibliometric analysis have been carried out on a sample of 1490 articles. The results show that the research has focused on the pollution of water bodies, climate change, the quality of water, the application of technology in order to make water use more efficient, biodiversity, erosion, agronomic practices that reduce water consumption, underground water sources, and conservation agriculture. Although research focusing on sustainability is still in its infancy, it has become a priority field. A gap in the research has been detected in terms of the economic and social dimensions of sustainability. There is also a lack of holistic studies that include all three of the pillars of sustainability (environmental, economic, and social).
\end{abstract}

Keywords: agriculture; water management; water resources; irrigation; sustainable management; sustainability; bibliometric analysis; Mexico

\section{Introduction}

Today's society must face a series of challenges in order to guarantee the survival of a constantly growing population, ensuring the same opportunities for future generations based on the principal of sustainability [1,2]. These include the supply of water and food, the eradication of hunger and poverty, and the conservation of a healthy natural environment $[3,4]$. These challenges are closely related to one another and are particularly relevant in the most disadvantaged regions. Agriculture is an economic activity that connects the different objectives proposed. It is the principal supplier of food on a global level. Therefore, it plays a fundamental role in food provision [5]. In addition, agriculture is one of the principal activities in rural areas. In some cases, it is the only possible activity and, therefore, the only engine of growth for the economies of these areas [6,7]. On the other hand, this sector is the principal consumer of water resources, so it has a direct impact on the availability of water $[8,9]$. Furthermore, agriculture is a source of environmental pollution and is too large of a degree responsible for the over-exploitation and degradation of water sources [10,11].

Mexican agriculture is a paradigmatic example of the relevance of this sector. According to data of the Food and Agriculture Organization of the United Nations (FAO), Mexico has a national territory of 198 million hectares, of which 145 million are dedicated to agricultural activity [12,13]. 
This area is divided into 30 million hectares for crops and 115 million for pastures. Although its share of Gross domestic product (GDP) is barely $4 \%$, agriculture is an important element for the country's development, as it constitutes a tool that helps to ensure food security $[14,15]$. Furthermore, it also forms a base for reinforcing progress and the growth of production, which can lead to improved standards of living and a greater production capacity of the rural sectors. Mexican agriculture is a fundamental activity for the rural environment, where 24 million Mexicans live, which is a quarter of the country's population. It also represents $50 \%$ of the revenue of this population $[13,15,16]$.

The extensive area of Mexico encompasses a diverse range of climate areas [17]. In general, two clearly differentiated areas can be distinguished. First, two-thirds of the country's territory has arid and semi-arid climates while the areas in the southern part of the country have a mild, tropical climate [12]. Overall, Mexico has 451,585 million cubic metres of renewable fresh water, taking into account rainfall, evapotranspiration, and the exit and entry flows of water with neighbouring countries [18]. The agricultural sector is the principal consumer of water, representing $76 \%$ of total consumption. In total, $63.6 \%$ of the water used in agricultural comes from surface sources and $36.4 \%$ of the water comes from underground sources. The National Water Plan 2019-2024 identifies the inefficient use of water as one of the problems related to water resources, particularly in the agricultural sector, which generates water losses of more than $40 \%$ [19].

In a global context, Mexico's overuse on its water resources is low, at 19.5\% [18]. However, two-thirds of its territory is in arid or semi-arid areas (north, centre, and north-east) with annual rainfalls of less than $500 \mathrm{~mm}$ [20]. Since the 1920s, large hydraulic infrastructures have benefited the northwest, contributing to the take-off of a modern and capitalist agriculture, but also a great demand for water. This is why, in these regions, there is a high level of overuse, which fluctuates between $40 \%$ and 100\% [18,19]. Furthermore, 105 of the 653 aquifers in Mexico are over-exploited, 32 have saline soil and brackish water, and 18 are affected by sea intrusion $[19,21]$. On the other hand, approximately 69 of the country's 757 water basins have deficits, as the flow granted or assigned exceeds that of the renewable water $[19,21]$. In addition, the possible effects derived from climate change could have a significant impact on water resources in the whole of the Mexican territory with the increase in temperature and the alteration of rainfall patterns. It is estimated, for example, that, by the end of the century, rainfall will have decreased by up to 30\% [19]. On the other hand, one of the principal problems highlighted by farmers in relation to the development of the agricultural activity is the loss of crops due to climate causes, particularly droughts [22]. The areas most affected by drought in recent years are Baja California, Sonora, and Sinaloa [18].

In recent years, the country has been boosting its agricultural activity and is now among the leading producers on a global level [12,23]. There has been a strong concentration of exports in fruit and vegetables in only one country (the United States). This is due to the increase of the presence of Mexican products in external markets, driven by the quality and variety of the produce, as well as the tariff advantages arising from the North American Free Trade Agreement (NAFTA). Furthermore, there is a need to feed the growing Mexican population, which is estimated to increase by $17 \%$ by 2050 [15]. The struggle to eradicate poverty is another reason to strengthen agriculture, given that almost $20 \%$ of the population is living below the national food poverty line, and $5 \%$ of the population is classified as undernourished [13]. Even so, the margin to improve the use of natural resources in Mexico is still wide and could increase the levels of agricultural production and productivity [24]. However, this commitment by the sector could put water resources at risk in the medium and long term $[20,25]$. In this situation, there is an urgent need to develop agricultural water management models aimed at guaranteeing the sustainability of a strategic sector for the Mexican economy, increasing production and ensuring the supply of water resources [26-28].

Within this context, an increasing number of contributions have been published that study the use of water in agriculture in Mexico. However, to date, no studies have analysed these contributions as a whole. Therefore, the objective of this article is to analyse the dynamics of the research on the use of water in agriculture in Mexico and its sustainable management. The methodology selected 
for achieving this objective is bibliometric analysis. Additionally, the results obtained will enable us to identify the principal driving agents of the knowledge in this field and the most relevant lines of research.

\section{Methodology}

\subsection{Bibliometric Analysis}

This methodology was developed in the middle of the last century in order to identify, organise, and evaluate the constituent elements of a specific field of study [29]. Today, bibliometric analysis has become one of the principal tools for reviewing a large amount of existing literature in any scientific discipline [30-32]. Its success is largely due to the availability of cartographic techniques for representing the bibliographic information stored in different databases and statistical and mathematical methods for determining the trends in a research field [33,34]. According to Durieux and Gevenois [35], bibliometric analysis can be based on three different kinds of indicators: quantity indicators, which measure productivity, relevance indicators, which show the impact of the publications, and structural indicators, which identify the connections between the different elements of the same research field. In this study, the three types of indicators are analysed and the traditional approach based on co-occurrence analysis is applied following Robinson et al. [36].

\subsection{Sample Selection}

The Scopus database has been chosen for selecting the sample of studies to analyse in this review because it is the largest database of abstracts and citations of peer-reviewed literature, it is the most accessible, it offers greater processing capabilities, and it is the most used in bibliometric studies on agriculture and water resources $[7,37,38]$. In addition, there are other search engines such as Web of Science (WoS), according to Gavel and Iselid [39]. Furthermore, $84 \%$ of the WoS titles are also indexed in Scopus, while only $54 \%$ of the Scopus titles are indexed in WoS. To carry out this study, two samples of studies were selected including one general sample on the use of water in agriculture in Mexico and another focused on its sustainable management. Both searches had common restrictions. The search was specified for the period of 1990 to 2019. This period is marked by the implementation of NAFTA, which is of great importance in shaping Mexico's export agriculture. Documents published in 2020 have not been included so that complete annual periods can be compared [40]. In order to avoid duplications, only original articles have been included in the sample [41]. The parameters used to select the sample of documents on the use of water in agriculture in Mexico were: TITLE-ABS-KEY (water OR irrigation

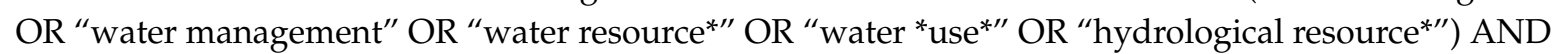
TITLE-ABS-KEY (agricultur* OR crop* OR farm* OR cultivation OR agrosystem* OR agroecosystem*) AND TITLE-ABS-KEY (Mexico OR Aguascalientes OR “Baja California” OR Campeche OR Chiapas OR Chihuahua OR Coahuila OR Colima OR Durango OR Guanajuato OR Guerrero OR Hidalgo OR Jalisco OR Michoacán OR Morelos OR Nayarit OR “Nuevo León” OR Oaxaca OR Puebla OR Querétaro OR “Quintana Roo" OR "San Luis Potosí" OR Sinaloa OR Sonora OR Tabasco OR Tamaulipas OR Tlaxcala OR Veracruz OR Yucatán OR Zacatecas). In order to obtain the second sample, the following was added to the parameters used in the first: TITLE-ABS-KEY (sustainab*). As a result, a final sample of 1490 articles on the use of water in agriculture in Mexico was obtained and 436 articles for the case of sustainable management were obtained. The selection of the sample was carried out in May 2020.

\subsection{Data Processing}

After selecting the samples of articles, the information was downloaded. The data were prepared before being analysed. To do this, duplications were eliminated, omissions and errors were corrected, and incomplete information was sought [42]. The analysis phase was then carried out. First, the evolution of the number of articles was examined, together with the subject areas in which the documents are classified in the Scopus database. Then the journals, institutions, and authors that 
had most published on the subject area, which is the object of this study, were identified, as were the principal international collaborations in the articles. The number of studies was used as the indicator of productivity. To evaluate the impact of the publications, the following quality indicators were selected: the counting of citations, the $\mathrm{H}$ index, and the impact factor of the Scimago Journal Rank journals (SJR). The $\mathrm{H}$ index shows the number $\mathrm{h}$ of a total of $\mathrm{N}$ documents that include $\mathrm{h}$ citations in each of them [43]. The SJR shows a weighting of the number of the citations received, taking into account the material and the prestige of the journal in which the citation is made [44]. Finally, cartographic techniques were used to visualise the co-occurrence network of keywords to determine the research trends [45]. The tools used were Excel (version 2016, Microsoft, Redmond, DC, USA), SciMaT (v1.1.04, Soft Computing and Intelligent Information Systems research group, University of Granada, Granada, Spain), and VOSviewer (version 1.6.5., Leiden University, Leiden, the Netherlands). The methodology described above has been used in other works [28,32,40]. Figure 1 shows an overall view of the methodology applied in this study.

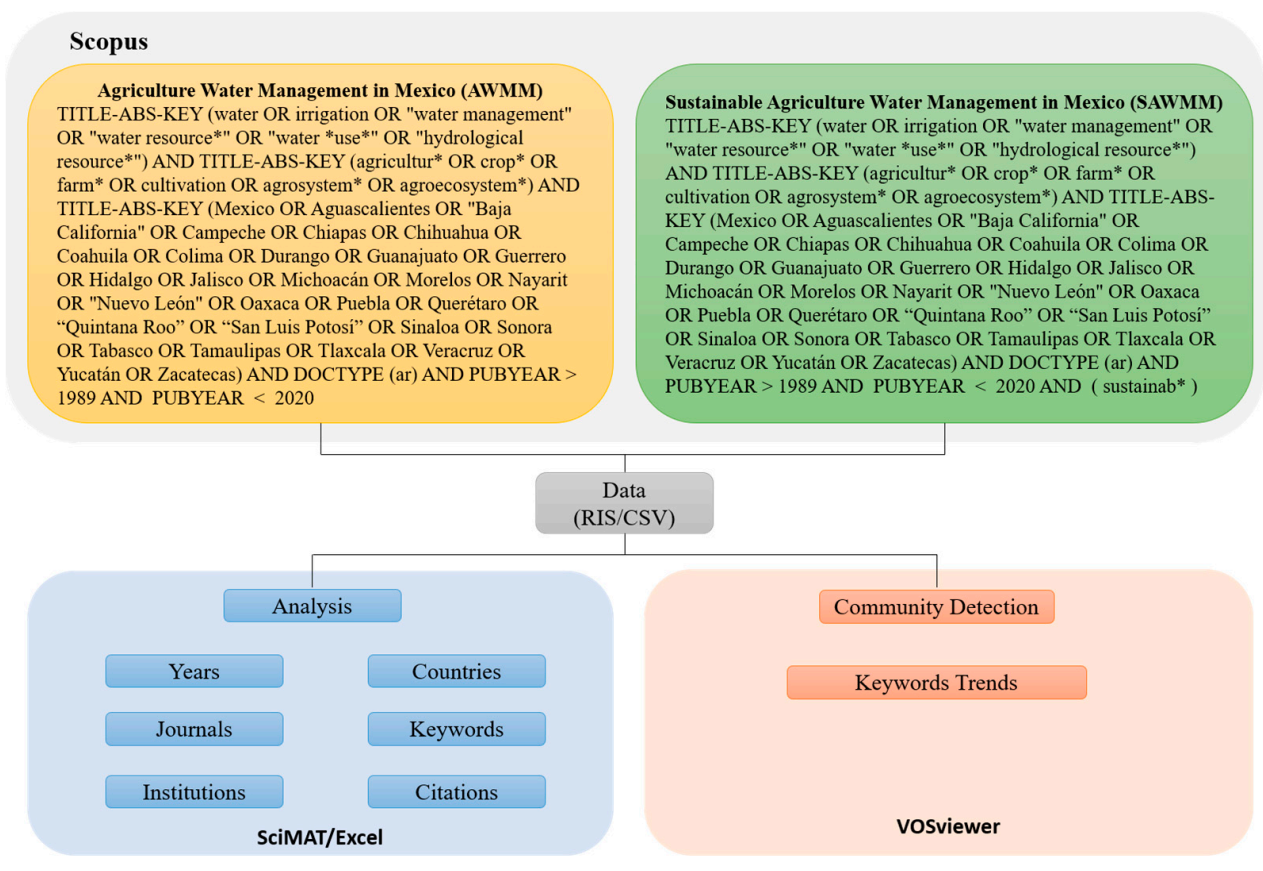

Figure 1. Summary of the methodology.

\section{Results and Discussion}

\subsection{General Evolution on Agricultural Water Management in Mexico Research}

Table 1 shows the evolution of the principal variables related to the research on agricultural water management in Mexico (AWMM) and sustainable agricultural water management in Mexico (SAWMM) in the period of 1990 to 2019. The total number of articles published in this period was 1490 in the case of research on AWMM and 436 in the case of SAWMM. The research on SAWMM represented $29.3 \%$ of the overall research on AWMM. The number of articles on AWMM increased from three in 1990 to 129 in 2019. In the case of the articles on SAWMM, in 1990, only one article was published, while, in 2019, this figure increased to 55. Both lines of research have gained importance in recent years, as $63.62 \%$ of the articles on AWMM and 73.85\% on SAWMM have been published in the last 10 years. After the year 2000, we can observe a point of inflection, where the research on SAWMM began to gain more relevance within the research on AWMM. The average annual growth of the articles on SAWMM was $14.8 \%$ while that of articles on AWMM was $13.9 \%$. This enables us to affirm that the research line on SAWMM has been gaining relevance within the general research on AWMM in recent years. 
Table 1. Major characteristics of agricultural water management research.

\begin{tabular}{|c|c|c|c|c|c|c|c|c|c|c|c|c|}
\hline \multirow{2}{*}{ Year } & \multicolumn{2}{|c|}{$\mathbf{A}$} & \multicolumn{2}{|c|}{$\mathrm{AU}$} & \multicolumn{2}{|c|}{$\mathrm{J}$} & \multicolumn{2}{|c|}{$\mathrm{C}$} & \multicolumn{2}{|c|}{ TC } & \multicolumn{2}{|c|}{ TC/CA } \\
\hline & SAWMM & AWMM & SAWMM & AWMM & SAWMM & AWMM & SAWMM & AWMM & SAWMM & AWMM & SAWMM & AWMM \\
\hline 1990 & 1 & 3 & 1 & 7 & 1 & 3 & 1 & 3 & 0 & 0 & 0.0 & 0.0 \\
\hline 1991 & 1 & 6 & 1 & 21 & 1 & 6 & 1 & 3 & 0 & 0 & 0.0 & 0.0 \\
\hline 1992 & 0 & 2 & 0 & 7 & 0 & 2 & 0 & 3 & 1 & 1 & 0.5 & 0.1 \\
\hline 1993 & 1 & 6 & 1 & 13 & 1 & 5 & 1 & 3 & 0 & 1 & 0.3 & 0.1 \\
\hline 1994 & 0 & 6 & 0 & 20 & 0 & 6 & 0 & 4 & 2 & 4 & 1.0 & 0.3 \\
\hline 1995 & 0 & 7 & 0 & 13 & 0 & 6 & 0 & 1 & 0 & 12 & 1.0 & 0.6 \\
\hline 1996 & 2 & 20 & 7 & 60 & 2 & 18 & 3 & 9 & 0 & 19 & 0.6 & 0.7 \\
\hline 1997 & 1 & 12 & 4 & 46 & 1 & 11 & 1 & 3 & 0 & 31 & 0.5 & 1.1 \\
\hline 1998 & 4 & 18 & 11 & 64 & 4 & 17 & 1 & 5 & 7 & 71 & 1.0 & 1.7 \\
\hline 1999 & 4 & 23 & 16 & 81 & 4 & 22 & 2 & 6 & 11 & 78 & 1.5 & 2.1 \\
\hline 2000 & 8 & 27 & 25 & 92 & 7 & 26 & 4 & 7 & 13 & 104 & 1.5 & 2.5 \\
\hline 2001 & 4 & 28 & 22 & 110 & 4 & 21 & 5 & 6 & 14 & 117 & 1.8 & 2.8 \\
\hline 2002 & 9 & 37 & 22 & 136 & 7 & 29 & 5 & 12 & 21 & 164 & 2.0 & 3.1 \\
\hline 2003 & 6 & 26 & 17 & 89 & 5 & 20 & 4 & 7 & 31 & 197 & 2.4 & 3.6 \\
\hline 2004 & 12 & 46 & 48 & 174 & 10 & 33 & 9 & 13 & 43 & 225 & 2.7 & 3.8 \\
\hline 2005 & 8 & 35 & 32 & 145 & 7 & 30 & 4 & 10 & 49 & 300 & 3.1 & 4.4 \\
\hline 2006 & 12 & 67 & 41 & 293 & 11 & 56 & 4 & 10 & 68 & 379 & 3.6 & 4.6 \\
\hline 2007 & 10 & 51 & 38 & 240 & 9 & 37 & 7 & 12 & 106 & 585 & 4.4 & 5.4 \\
\hline 2008 & 17 & 58 & 67 & 259 & 15 & 49 & 4 & 10 & 119 & 652 & 4.9 & 6.2 \\
\hline 2009 & 14 & 64 & 63 & 275 & 11 & 52 & 8 & 18 & 203 & 812 & 6.0 & 6.9 \\
\hline 2010 & 10 & 51 & 48 & 242 & 9 & 41 & 3 & 9 & 178 & 889 & 7.0 & 7.8 \\
\hline 2011 & 28 & 90 & 111 & 380 & 22 & 60 & 9 & 14 & 235 & 1023 & 7.2 & 8.3 \\
\hline 2012 & 26 & 73 & 106 & 312 & 24 & 60 & 11 & 18 & 271 & 1210 & 7.7 & 9.1 \\
\hline 2013 & 24 & 96 & 109 & 422 & 21 & 67 & 8 & 20 & 365 & 1334 & 8.6 & 9.6 \\
\hline 2014 & 24 & 81 & 104 & 413 & 22 & 63 & 7 & 21 & 431 & 1617 & 9.6 & 10.5 \\
\hline 2015 & 26 & 98 & 121 & 490 & 24 & 75 & 10 & 21 & 453 & 1789 & 10.4 & 11.3 \\
\hline 2016 & 36 & 87 & 161 & 412 & 30 & 69 & 13 & 15 & 512 & 1941 & 10.9 & 12.1 \\
\hline 2017 & 50 & 127 & 236 & 601 & 43 & 86 & 13 & 21 & 564 & 2107 & 10.9 & 12.6 \\
\hline 2018 & 43 & 116 & 315 & 676 & 34 & 73 & 9 & 14 & 699 & 2430 & 11.5 & 13.3 \\
\hline 2019 & 55 & 129 & 295 & 651 & 45 & 95 & 14 & 25 & 833 & 2782 & 12.2 & 14.1 \\
\hline
\end{tabular}

A: The annual number of total articles. AU: the annual number of authors. J: the annual number of journals. C: the annual number of countries. TC: the annual number of citations in cumulative articles. TC/CA: annual total citation per cumulative article. 
During the whole period analysed, a total of 5314 authors participated in the 1490 articles on AWMM. In the case of research on SAWMM, 1759 authors collaborated on the 436 articles published on this subject matter. In both cases, this variable has grown considerably. Specifically, the number of authors grew from seven in 1990 to 651 in 2019 in the case of research on AWMM and from one to 295 in the case of research on SAWMM. The average number of authors per article increased from 2.33 to 5.04 in the research on AWMM and from one to 5.36 in that on SAWMM. In total, 1490 articles on AWMM were published in 541 different journals, while 436 articles on SAWMM were published in 226 journals. The average number of articles per journal remained practically constant during the whole period at around one in the case of research on SAWMM and 1.22 in the case of research on AWMM. With respect to the countries that participated in carrying out the studies, during the whole period analysed, there were a total of 54 for AWMM and 35 for SAWMM. The number of countries increased from three to 25 for AWMM and from one to 14 for SAWMM.

In the case of citations, as a whole, the studies on AWMM obtained a total of 20,874 citations during the whole period analysed, while, in the case of SAWMM, there were 5229. The citations in the case of SAWMM represent around $25 \%$ of the total citations obtained in the general subject area. The number of citations increased from one in 1992 to 2782, and 833 in 2019, for the articles on AWMM and SAWMM, respectively. The average number of citations obtained per article increased from 0.1 to 14.1 in the research on AWMM and from 0.5 to 12.2 in that on SAWMM.

\subsection{Evolution of Research by Subject Area}

Table 2 shows the number of articles published during the whole period analysed in both lines of research, classified in accordance with the subject categories established by Scopus. It should be taken into account that the same article may be classified in more than one category simultaneously. As we can see, in both lines of research, the categories with the highest number of articles are Environmental Sciences, Agricultural and Biological Sciences, and Earth and Planetary Sciences. In the period of 1990 to $2019,54.4 \%$ of the articles on AWMM were published under the category Environmental Sciences, $49.6 \%$ in the category of Agricultural and Biological Sciences, and $16.3 \%$ in the category of Earth and Planetary Sciences. In the case of research on SAWMM, these percentages were $62.2 \%, 47.5 \%$, and $15.1 \%$, respectively. In general, in both lines of research, the categories related to environmental and technical fields predominated.

Table 2. Number of articles published by subject category.

\begin{tabular}{|c|c|c|c|c|c|}
\hline AWMM & Total & $\%$ & SAWMM & Total & $\%$ \\
\hline Environmental Sciences & 810 & 54.4 & Environmental Sciences & 271 & 62.2 \\
\hline Agricultural and Biological Sciences & 724 & 49.6 & $\begin{array}{l}\text { Agricultural and Biological } \\
\text { Sciences }\end{array}$ & 207 & 47.5 \\
\hline Earth and Planetary Sciences & 243 & 16.3 & Earth and Planetary Sciences & 66 & 15.1 \\
\hline Engineering & 144 & 10.7 & Social Sciences & 64 & 14.7 \\
\hline Biochemistry, Genetics, and Molecular Biology & 123 & 8.3 & Engineering & 45 & 10.3 \\
\hline Social Sciences & 121 & 8.1 & $\begin{array}{c}\text { Biochemistry, Genetics, and } \\
\text { Molecular Biology }\end{array}$ & 39 & 9.9 \\
\hline Medicine & 79 & 5.3 & Energy & 28 & 6.4 \\
\hline Immunology and Microbiology & 62 & 4.2 & Chemical Engineering & 11 & 2.5 \\
\hline Pharmacology, Toxicology, and Pharmaceutics & 60 & 4.0 & Medicine & 11 & 2.5 \\
\hline Business, Management, and Accounting & 15 & 1.0 & $\begin{array}{c}\text { Business, Management, and } \\
\text { Accounting }\end{array}$ & 9 & 2.1 \\
\hline Economics, Econometrics, and Finance & 13 & 0.9 & $\begin{array}{c}\text { Economics, Econometrics, } \\
\text { and Finance }\end{array}$ & 9 & 2.1 \\
\hline
\end{tabular}

Sustainability spans across three fields: environmental, economic, and social. In the case of research on SAWMM, higher percentages were found in the categories of the social and economic dimensions, showing the greater importance that these areas have in this line of research. Specifically, the Social Sciences category represents $14.7 \%$ in the case of SAWMM while it only accounts for $8.1 \%$ in the case of AWMM. The economic categories (Economics, Econometrics and Finance, and Business, 
Management, and Accounting) represent $4.2 \%$ in the case of SAWMM and only $1.9 \%$ in the case of research on AWMM. Therefore, although the social and economic fields have a greater relevance in the case of research related to sustainability, the still incipient nature of this line of research means that it still has not reached values similar to those in the environmental field. Hence, it is necessary to broaden the research from the social and economic perspectives and carry out holistic studies that take into account all three dimensions of sustainability.

\subsection{Most Relevant Journals}

Tables 3 and 4 show the most prolific journals in terms of AWMM and SAWMM research in the period of 1990 to 2019 and the principal characteristics of their articles. If we compare the two tables, we can observe that only five journals have published on both subject areas (Tecnologia y Ciencias del Agua, Agrociencia, Revista Internacional de Contaminación Ambiental, Science of the Total Environment, and Soil and Tillage Research). Furthermore, in both cases, the journal with the highest number of articles published is Tecnologia y Ciencias del Agua. If we analyse Table 3, we can see that the principal journals in the case of research on AWMM are from five different countries, three in Europe (UK, Spain, and Netherlands) and two in America (Mexico and USA). In total, this group of journals has published 336 articles within the sample, which represent $22.6 \%$ of the total. These data do not enable us to confirm whether there is a central nucleus of journals that leads this line of publication. Tecnologia $y$ Ciencias del Agua, with a total of 102 articles, is the journal that published the most articles on AWMM. This journal has an $\mathrm{H}$ index of 6 , a total of 165 citations, and its average number of citations per article is 1.6. Moreover, it has a Scimago Journal Rank (SJR) impact factor of 0.195 and has been publishing on AWMM since the year 2000. With almost half the number of articles, it is followed by the journals Agrociencia and Revista Internacional de Contaminación Ambiental, which have published a total of four articles each. Agrociencia has an $\mathrm{H}$ index of 7, a total of 155 citations, and 3.4 citations per article and its SJR impact factor is 0.181. Revista Internacional de Contaminación Ambiental, meanwhile, has an $\mathrm{H}$ index of 8, a total of 211 citations, an average number of citations per article of 4.6, and an SJR impact factor of 0.190. Despite having published only 16 articles on the subject area, the journal Soil and Tillage Research has the highest $\mathrm{H}$ index in the entire table (12). Furthermore, it has the highest values of the total citations and average number of citations per article with 557 and 34.8, respectively. The journal that has been publishing on the subject for the longest is Bulletin of Environmental Contamination and Toxicology, as it published its first articles on the subject in 1993 and continues publishing in this line of research today.

Table 3. Major characteristics of the most active journals related to agricultural water management in Mexico (AWMM) research.

\begin{tabular}{|c|c|c|c|c|c|c|c|c|}
\hline Journal & A & SJR & $\mathrm{H}$ index & $\mathrm{C}$ & TC & TC/A & 1st A & Last A \\
\hline Tecnologia y Ciencias del Agua* & 102 & $0.195(Q 3)$ & 6 & Mexico & 165 & 1.6 & 2000 & 2019 \\
\hline Agrociencia & 46 & $0.181(\mathrm{Q} 3)$ & 7 & Mexico & 155 & 3.4 & 2004 & 2019 \\
\hline $\begin{array}{l}\text { Revista Internacional de Contaminacion } \\
\text { Ambiental }\end{array}$ & 46 & $0.190(Q 4)$ & 8 & Mexico & 211 & 4.6 & 1998 & 2019 \\
\hline $\begin{array}{c}\text { Bulletin of Environmental Contamination } \\
\text { and Toxicology }\end{array}$ & 24 & $0.515(\mathrm{Q} 2)$ & 11 & USA & 306 & 12.8 & 1993 & 2019 \\
\hline Water Science and Technology & 20 & $0.471(\mathrm{Q} 2)$ & 11 & UK & 341 & 17.1 & 1995 & 2016 \\
\hline Investigaciones Geograficas & 18 & $0.190(Q 3)$ & 4 & Spain & 48 & 2.7 & 2004 & 2017 \\
\hline Agricultural Water Management & 16 & 1.369 (Q1) & 10 & Netherlands & 289 & 18.1 & 1999 & 2018 \\
\hline Environmental Monitoring and Assessment & 16 & $0.571(\mathrm{Q} 2)$ & 9 & Netherlands & 144 & 9.0 & 2000 & 2019 \\
\hline Science of the Total Environment & 16 & $1.661(\mathrm{Q} 1)$ & 9 & Netherlands & 295 & 18.4 & 2006 & 2019 \\
\hline Soil and Tillage Research & 16 & $1.791(\mathrm{Q} 1)$ & 12 & Netherlands & 557 & 34.8 & 2000 & 2018 \\
\hline $\begin{array}{c}\text { Wit Transactions on Ecology and } \\
\text { the Environment }\end{array}$ & 16 & $0.142(\mathrm{Q} 4)$ & 2 & UK & 14 & 0.9 & 2006 & 2019 \\
\hline
\end{tabular}

A: the annual number of total articles. SJR: Scimago Journal Ranking. C: country. TC: the annual number of citations in total articles. TC/A: total citation per article. 1st A: first article of SPMM research by journal. Last A: last article. * Includes Ingenieria Hidraulica En Mexico. This journal changed its name in 2009. In 2010, it became Tecnologia $y$ Ciencias del Agua. 
Table 4. Major characteristics of the most active journals related to sustainable agricultural water management in Mexico (SAWMM) research.

\begin{tabular}{|c|c|c|c|c|c|c|c|c|}
\hline Journal & A & SJR & $\mathrm{H}$ index & $\mathrm{C}$ & TC & TC/A & 1st A & Last A \\
\hline Tecnologia y Ciencias del Agua * & 29 & $0.195(Q 3)$ & 3 & Mexico & 48 & 1.7 & 2004 & 2019 \\
\hline $\begin{array}{c}\text { Revista Internacional de Contaminacion } \\
\text { Ambiental }\end{array}$ & 12 & $0.190(\mathrm{Q} 4)$ & 4 & Mexico & 38 & 3.2 & 2011 & 2018 \\
\hline Soil and Tillage Research & 11 & $1.791(\mathrm{Q} 1)$ & 10 & Netherlands & 477 & 43.4 & 2000 & 2018 \\
\hline Water & 11 & $0.657(\mathrm{Q} 1)$ & 4 & Switzerland & 39 & 3.5 & 2012 & 2019 \\
\hline Agrociencia & 10 & $0.181(\mathrm{Q} 3)$ & 2 & Mexico & 13 & 1.3 & 2007 & 2019 \\
\hline Sustainability & 8 & $0.581(\mathrm{Q} 2)$ & 3 & Switzerland & 21 & 2.6 & 2015 & 2019 \\
\hline Agriculture Ecosystems and Environment & 7 & 1.719 (Q1) & 6 & Netherlands & 235 & 33.6 & 1991 & 2018 \\
\hline Ecological Engineering & 7 & $1.122(\mathrm{Q} 1)$ & 4 & Netherlands & 37 & 5.3 & 2013 & 2019 \\
\hline Environmental Earth Sciences & 7 & $0.604(\mathrm{Q} 2)$ & 5 & Germany & 50 & 7.1 & 2010 & 2019 \\
\hline Field Crops Research & 7 & $1.767(\mathrm{Q} 1)$ & 5 & Netherlands & 349 & 49.9 & 2002 & 2018 \\
\hline Science of the Total Environment & 7 & $1.661(\mathrm{Q} 1)$ & 5 & Netherlands & 45 & 6.4 & 2012 & 2019 \\
\hline
\end{tabular}

A: the annual number of total articles. SJR: Scimago Journal Ranking. C: country. TC: the annual number of citations in total articles. TC/A: total citation per article. 1st A: first article of SPMM research by journal. Last A: last article. * Includes Ingenieria Hidraulica En Mexico. This journal changed its name in 2009. In 2010, it became Tecnologia y Ciencias del Agua.

Meanwhile, if we analyse the research on SAWMM, we can see that the principal journals belong to only four countries, including three in Europe (Netherlands, Switzerland, and Germany) and Mexico. In this case, the total articles published by these journals during the period analysed represent $26.6 \%$ of the total. Tecnologia y Ciencias del Agua is also the journal with the highest number of articles published, with a total of 29. This journal has an $\mathrm{H}$ index of 3, a total of 48 citations, and its average number of citations per article is 1.7. This journal began to publish on AWMM in the year 2000 and on SAWMM in 2004. The Revista Internacional de Contaminación Ambiental is the journal with the second highest number of articles with a total of 12. It has an $\mathrm{H}$ index of 4 and 38 citations in total. This journal obtained 3.2 citations per article. It began to publish on AWMM in 1998 and published its first article on SAWMM in 2011. It is followed by the journals Soil and Tillage Research and Water, with 11 articles each. Soil and Tillage Research has the highest $\mathrm{H}$ index of the group (10) and also the highest average number of citations per article (43.4 citations per article). The journal Water has an $\mathrm{H}$ index of 4 , a total of 39 citations, and its average number of citations per article is 3.5. The journal that has been publishing in the research on SAWMM for the longest in the table is Agriculture, Ecosystems, and Environment, which published its first article on the subject in 1991, even though it has only published seven articles in total.

\subsection{International Collaboration}

Table 5 shows the results of the analysis of the collaboration networks established between Mexico and its principal collaborators in the research on AWMM and SAWMM. The average percentage of studies carried out through international collaboration is higher in the research on SAWMM than in the case of AWMM with $41.3 \%$ and $35.5 \%$, respectively. This difference can be explained because the research on sustainability is considered as being more multidisciplinary and, therefore, more collaborative. The table also shows the principal international collaborators in both cases, with the majority being common to both. If we analyse the differences, in the case of research on AWMM, we find Italy and China in the group of principal collaborators while, in the case of research on SAWMM, Saudi Arabia is incorporated. Seven of the principal collaborators in the case of the research on SAWMM are from the most prolific countries with respect to research on a global level on Sustainable Water Use in Agriculture (USA, Spain, Germany, France, Australia, UK, and Netherlands) [42]. It is noteworthy that, although China is the most important country on a global level in research on SWUA, it does not appear among the most important collaborators in the case of research on Mexico. In terms of the number of citations, the articles carried out through international collaboration have a higher average number in both lines of research than the articles carried out without an international collaboration. 
Table 5. Main characteristics of the international collaboration of Mexico related to AWMM and SAWMM research.

\begin{tabular}{|c|c|c|c|c|c|}
\hline & \multirow{2}{*}{ IC (\%) } & \multirow{2}{*}{ NC } & \multirow{2}{*}{ Main Collaborators } & \multicolumn{2}{|c|}{ TC/A } \\
\hline & & & & IC & NIC \\
\hline AWMM & 35.5 & 59 & $\begin{array}{c}\text { USA, Spain, Germany, France, } \\
\text { Canada, UK, Australia, } \\
\text { Belgium, Italy, Chile, Netherlands }\end{array}$ & 22.7 & 9.2 \\
\hline SAWMM & 41.3 & 36 & $\begin{array}{l}\text { USA, Spain, Germany, Canada, } \\
\text { France, Belgium, Australia, } \\
\text { UK, Netherlands, Saudi Arabia }\end{array}$ & 19.7 & 6.6 \\
\hline
\end{tabular}

IC: international collaborations. NC: total number of international collaborators. TC/A: total citation per article. NIC: no international collaborations.

\subsection{Most Relevant Institutions}

Tables 6 and 7 show the most prolific institutions in terms of AWMM and SAWMM research in the period of 1990 to 2019 and the principal characteristics of their articles. In both cases, all of the institutions are in Mexico except for the University of Arizona in the USA. The majority of the institutions have published in both lines of research except for the Centro de Investigaciones Biológicas del Noroeste, Universidad Autónoma de Chapingo, Universidad de Sonora, Universidad Michoacana de San Nicolás de Hidalgo and Tecnológico de Monterrey.

Table 6. Major characteristics of the most active institutions related to AWMM research.

\begin{tabular}{|c|c|c|c|c|c|c|c|c|}
\hline \multirow{2}{*}{ Institution } & \multirow{2}{*}{$\mathrm{C}$} & \multirow{2}{*}{$\mathbf{A}$} & \multirow{2}{*}{ TC } & \multirow{2}{*}{ TC/A } & \multirow{2}{*}{$\begin{array}{c}\mathbf{H} \\
\text { Index }\end{array}$} & \multirow{2}{*}{$\begin{array}{l}\text { IC } \\
(\%)\end{array}$} & \multicolumn{2}{|c|}{ TC/A } \\
\hline & & & & & & & IC & NIC \\
\hline Universidad Nacional Autónoma de México & Mexico & 338 & 5723 & 16.9 & 40 & 28.4 & 23.6 & 14.3 \\
\hline Colegio de Postgraduados & Mexico & 122 & 1378 & 11.3 & 14 & 26.2 & 32.7 & 3.7 \\
\hline $\begin{array}{c}\text { Instituto Nacional de Investigaciones Forestales, } \\
\text { Agricolas y Pecuarias }\end{array}$ & Mexico & 117 & 1118 & 9.6 & 15 & 33.3 & 20.1 & 4.3 \\
\hline Instituto Politécnico Nacional & Mexico & 97 & 877 & 9.0 & 17 & 18.6 & 12.9 & 8.2 \\
\hline Centro Internacional de Mejoramiento de Maiz y Trigo & Mexico & 74 & 4583 & 61.9 & 36 & 82.4 & 61.3 & 64.8 \\
\hline Centro de Investigaciones Biologicas Del Noroeste & Mexico & 65 & 732 & 11.3 & 16 & 24.6 & 8.4 & 12.2 \\
\hline Instituto Mexicano de Tecnologia del Agua & Mexico & 64 & 363 & 5.7 & 13 & 23.4 & 3.7 & 6.3 \\
\hline Universidad Autónoma de Chapingo & Mexico & 60 & 347 & 5.8 & 9 & 25.0 & 12.8 & 3.4 \\
\hline Universidad de Sonora & Mexico & 49 & 530 & 10.8 & 15 & 30.6 & 12.3 & 10.1 \\
\hline University of Arizona & USA & 48 & 992 & 20.7 & 16 & 100.0 & 20.7 & 0.0 \\
\hline Instituto de Ecología, A.C. & Mexico & 48 & 577 & 12.0 & 14 & 37.5 & 18.9 & 7.9 \\
\hline
\end{tabular}

C: country. A: the annual number of total articles. TC: the annual number of citations in total articles. TC/A: total citation per article. IC: international collaborations. NIC: no international collaborations.

Table 7. Major characteristics of the most active institutions related to SAWMM research.

\begin{tabular}{|c|c|c|c|c|c|c|c|c|}
\hline \multirow{2}{*}{ Institution } & \multirow{2}{*}{$\mathrm{C}$} & \multirow{2}{*}{ A } & \multirow{2}{*}{ TC } & \multirow{2}{*}{ TC/A } & \multirow{2}{*}{$\begin{array}{c}\mathrm{H} \\
\text { Index }\end{array}$} & \multirow{2}{*}{$\begin{array}{l}\text { IC } \\
(\%)\end{array}$} & \multicolumn{2}{|c|}{ TC/A } \\
\hline & & & & & & & IC & NIC \\
\hline Universidad Nacional Autónoma de México & Mexico & 82 & 969 & 11.8 & 17 & 29.3 & 10.9 & 12.2 \\
\hline Centro Internacional de Mejoramiento de Maiz y Trigo & Mexico & 32 & 1337 & 41.8 & 22 & 81.3 & 43.8 & 33.2 \\
\hline $\begin{array}{c}\text { Instituto Nacional de Investigaciones Forestales, } \\
\text { Agricolas y Pecuarias }\end{array}$ & Mexico & 29 & 436 & 15.0 & 9 & 48.3 & 23.4 & 7.3 \\
\hline Colegio de Postgraduados & Mexico & 28 & 304 & 10.9 & 6 & 35.7 & 26.2 & 2.3 \\
\hline Instituto Politécnico Nacional & Mexico & 27 & 184 & 6.8 & 9 & 18.5 & 4.6 & 7.3 \\
\hline University of Arizona & USA & 23 & 383 & 16.7 & 10 & 100.0 & 16.7 & 0.0 \\
\hline Instituto Mexicano de Tecnologia del Agua & Mexico & 22 & 71 & 3.2 & 4 & 31.8 & 4.7 & 2.5 \\
\hline Universidad Michoacana de San Nicolás de Hidalgo & Mexico & 19 & 153 & 8.1 & 7 & 42.1 & 15.0 & 3.0 \\
\hline Instituto de Ecología, A.C. & Mexico & 18 & 183 & 10.2 & 8 & 33.3 & 15.8 & 7.3 \\
\hline Tecnologico de Monterrey & Mexico & 17 & 155 & 9.1 & 7 & 47.1 & 16.8 & 2.3 \\
\hline
\end{tabular}

C: country. A: the annual number of total articles. TC: the annual number of citations in total articles. TC/A: total citation per article. IC: international collaborations. NIC: no international collaborations. 
In the research on AWMM, the Universidad Nacional Autónoma de México is in first place with 338 articles. It has the highest total number of citations with 5723, an average of 16.9 citations per article, and an $\mathrm{H}$ index of 40 . This is followed by the Colegio de Postgraduados with 122 articles, 1378 citations, an average of 11.3 citations per article, and an $\mathrm{H}$ index of 14 . Next is the Instituto Nacional de Investigaciones Forestales, Agrícolas y Pecuarias with 117 articles, a total of 1118 citations, an average of 9.6 citations per article, and an $\mathrm{H}$ index of 15 . The Centro Internacional de Mejoramiento de Maiz y Trigo holds the fifth position in terms of the number of articles with a total of 74 and it is the institution with the highest average number of citations per article at 61.9. Furthermore, it has a total number of citations of 4583 and an $\mathrm{H}$ index of 36 . With respect to the international collaboration of the institutions, the average percentage of articles carried out through collaboration is $39.1 \%$. In this respect, The University of Arizona reveals $100 \%$ of collaboration, given that the whole of the sample has had the participation of a Mexican institution. The Centro Internacional de Mejoramiento de Maiz y Trigo, with $82.4 \%$, is the Mexican institution with the highest percentage of an international collaboration. The average number of citations in the articles written through international collaboration was 20.7 while, for the rest of the articles, it was 12.3 .

In the case of research on SAWMM, the first position is also held by the Universidad Nacional Autónoma de México with 82 articles. Furthermore, it has an $\mathrm{H}$ index of 17 and a total of 969 citations. The institution with the second highest number of articles is the Centro Internacional de Mejoramiento de Maiz y Trigo with 32 articles. This institution has 1337 citations and the highest $\mathrm{H}$ index of the group with 22. It also has the highest average number of citations per article (41.8). Next is the Instituto Nacional de Investigaciones Forestales, Agricolas y Pecuarias, which has 29 articles, 436 citations, and an $\mathrm{H}$ index of 9 . The average number of citations of the articles written through international collaboration in this group of institutions was 17.8 as opposed to 7.7 in the rest.

\subsection{Most Relevant Authors}

Tables 8 and 9 include the most productive authors in the research on AWMM and SAWMM and show the most salient characteristics of their articles. In general, these groups of authors are affiliated to nine different institutions in three countries. As we would expect, the majority of the authors are affiliated with a Mexican institution. There are only two authors affiliated with an American entity and another with a Belgian institution. The majority of the authors have published in both lines of research. In the case of research on AWMM, the author with the highest number of articles is Federico Páez-Osuna with a total of 28. Furthermore, this author has been publishing on this subject matter for a long time, as his first article was published in 1993 and he continues to publish today. His articles have received a total of 753 citations, an average number of citations per article of 26.9 , and an $\mathrm{H}$ index of 15 . He is followed by Christina D. Siebe with 26 articles. This author has accumulated a total of 807 citations, has an average of 31.1 citations per article, and an $\mathrm{H}$ index of 16 . The following author is Bram Govaerts with 19 articles. This author accumulates a total of 675 citations, an average of 35.5 citations per article, and an $\mathrm{H}$ index of 13. This is the only author who does not belong to a Mexican institution. Matthew P. Reynolds is the author with the highest number of citations with a total of 1723 and the highest average number of citations per article with 95.7.

In the research on SAWMM, we find that the most prolific author, with 17 articles, is Bram Govaerts. This author also has the highest number of citations with a total of 650 and the highest $\mathrm{H}$ index (12). The average number of citations per article of this author is higher in the case of research on SAWMM than in general research (38.2 and 35.5 citations, respectively). The following author is Nele Verhulst with 13 articles. This author has a total of 278 citations and an $\mathrm{H}$ index of 8 . The average number of citations per article obtained by this author in the case of research on SAWMM is 21.4 citations, as opposed to 20.2 citations of general research. The next author is José María Ponce-Ortega with 11 articles. This author accumulates a total of 116 citations, an average of 10.5 citations per article, and an $\mathrm{H}$ index of six. Jozef A. Deckers, affiliated with an institution in Belgium, is the author with the highest average number of citations per article (75.3). The most veteran 
author is also, in this case, Federico Páez-Osuna, who began to publish on SAWMM in 1998 and still does today.

Table 8. Major characteristics of the most active authors related to AWMM research.

\begin{tabular}{|c|c|c|c|c|c|c|c|c|}
\hline Author & $\mathbf{A}$ & TC & TC/A & $\begin{array}{c}\mathrm{H} \\
\text { Index }\end{array}$ & C & Affiliation & $\begin{array}{c}\text { First } \\
\text { Article }\end{array}$ & $\begin{array}{c}\text { Last } \\
\text { Article }\end{array}$ \\
\hline Páez-Osuna, Federico & 28 & 753 & 26.9 & 15 & Mexico & $\begin{array}{c}\text { Universidad Nacional Autónoma } \\
\text { de México }\end{array}$ & 1993 & 2019 \\
\hline Siebe, Christina D. & 26 & 807 & 31.1 & 16 & Mexico & $\begin{array}{c}\text { Universidad Nacional Autónoma } \\
\text { de México }\end{array}$ & 1995 & 2019 \\
\hline Govaerts, Bram & 19 & 675 & 35.5 & 13 & USA & Cornell University & 2006 & 2018 \\
\hline Dendooven, Luc & 18 & 529 & 29.4 & 13 & Mexico & $\begin{array}{l}\text { Centro de Investigacion y de } \\
\text { Estudios Avanzados }\end{array}$ & 2002 & 2019 \\
\hline Reynolds, Matthew P. & 18 & 1723 & 95.7 & 16 & Mexico & $\begin{array}{c}\text { Centro Internacional de } \\
\text { Mejoramiento de Maiz y Trigo }\end{array}$ & 1996 & 2016 \\
\hline Verhulst, Nele & 15 & 303 & 20.2 & 9 & Mexico & $\begin{array}{l}\text { Centro Internacional de } \\
\text { Mejoramiento de Maiz y Trigo }\end{array}$ & 2011 & 2019 \\
\hline Ruiz-Fernández, Ana C. & 14 & 496 & 35.4 & 11 & Mexico & $\begin{array}{c}\text { Universidad Nacional Autónoma } \\
\text { de México }\end{array}$ & 1997 & 2016 \\
\hline Sayre, Kenneth D. & 14 & 1195 & 85.4 & 14 & Mexico & $\begin{array}{l}\text { Centro Internacional de } \\
\text { Mejoramiento de Maiz y Trigo }\end{array}$ & 1998 & 2012 \\
\hline López-López, Eugenia & 13 & 227 & 17.5 & 8 & Mexico & Instituto Politécnico Nacional & 1998 & 2018 \\
\hline Mahlknecht, Jürgen & 13 & 340 & 26.2 & 9 & Mexico & Tecnologico de Monterrey & 2004 & 2019 \\
\hline
\end{tabular}

A: the annual number of total articles. TC: total number of citations in total articles. TC/A: total citations per article. C: country.

Table 9. Major characteristics of the most active authors related to SAWMM research.

\begin{tabular}{|c|c|c|c|c|c|c|c|c|}
\hline Author & A & TC & TC/A & $\begin{array}{c}\mathrm{H} \\
\text { Index }\end{array}$ & $\mathrm{C}$ & Affiliation & $\begin{array}{c}\text { 1st } \\
\text { Article }\end{array}$ & $\begin{array}{l}\text { Last } \\
\text { Article }\end{array}$ \\
\hline Govaerts, Bram & 17 & 650 & 38.2 & 12 & USA & Cornell University & 2006 & 2018 \\
\hline Verhulst, Nele & 13 & 278 & 21.4 & 8 & Mexico & $\begin{array}{c}\text { Centro Internacional de } \\
\text { Mejoramiento de Maiz y Trigo }\end{array}$ & 2011 & 2019 \\
\hline $\begin{array}{l}\text { Ponce-Ortega, José } \\
\text { María }\end{array}$ & 11 & 116 & 10.5 & 6 & Mexico & $\begin{array}{l}\text { Universidad Michoacana de San } \\
\text { Nicolás de Hidalgo }\end{array}$ & 2012 & 2019 \\
\hline Sayre, Kenneth D. & 9 & 535 & 59.4 & 9 & Mexico & $\begin{array}{c}\text { Centro Internacional de } \\
\text { Mejoramiento de Maiz y Trigo }\end{array}$ & 2006 & 2012 \\
\hline Páez-Osuna, Federico & 7 & 189 & 27.0 & 6 & Mexico & $\begin{array}{l}\text { Universidad Nacional Autónoma } \\
\text { de México }\end{array}$ & 1998 & 2019 \\
\hline Siebe, Christina D. & 7 & 149 & 21.3 & 5 & Mexico & $\begin{array}{c}\text { Universidad Nacional Autónoma } \\
\text { de México }\end{array}$ & 2012 & 2019 \\
\hline Deckers, Jozef A. & 6 & 452 & 75.3 & 6 & Belgium & University of Leuven & 2006 & 2011 \\
\hline Dendooven, Luc & 6 & 221 & 36.8 & 5 & Mexico & $\begin{array}{c}\text { Centro de Investigacion y de } \\
\text { Estudios Avanzados }\end{array}$ & 2009 & 2019 \\
\hline $\begin{array}{l}\text { El-Halwagi, Mahmoud } \\
\text { M. }\end{array}$ & 6 & 109 & 18.2 & 5 & USA & Texas A\&M University & 2012 & 2017 \\
\hline Mahlknecht, Jürgen & 6 & 80 & 13.3 & 5 & Mexico & Tecnologico de Monterrey & 2008 & 2019 \\
\hline
\end{tabular}

A: the annual number of total articles. TC: total number of citations in total articles. TC/A: total citation per article.

C: country.

\subsection{Keywords Analysis}

Figures 2 and 3 show the network maps of keywords in the different lines of research on AWMM and SAWMM. The size of the circle varies depending on the number of times the term has been used, while the colour represents the group in which the keyword is included depending on the number of co-occurrences.

As could be expected, in Figure 2, we can find a large number of different clusters (a total of 9), reflecting the diversity of the topics within the general research. The red cluster refers to the pollution of water bodies. In Mexico, more than half of the waste water is not treated [46]. The uncontrolled discharging of untreated, reused water can generate negative effects derived from the pollution of water bodies and agricultural soils [47]. Pérez-Castresana et al. [48] find, for example, that the quality of the water of the River Atoyacd, on which the agricultural activities greatly depend in the area of Puebla, has been compromised due to the discharging of large amounts of poorly treated waste water. 
Meanwhile, the application of fertilizers has also been shown to be a cause of pollution of water and agricultural soils [49]. García-Hernández et al. [24] analysed the research on the effect of the use of pesticides in Mexico, finding that they have had negative impacts on the land and coastal ecosystems and on the health of the agricultural workers and their families.

The green cluster refers to the effects of climate change on the availability and management of water. Hernández-Bedolla et al. [50] developed indices to evaluate the availability of water in different scenarios, concluding that the principal factors that affect its availability are the decrease in rainfall and the high temperatures. A study on the possible effects of climate change on the Guadalupe River basin in the north of Mexico shows that the run-off could decrease by anywhere from $45 \%$ to $60 \%$ while the recharging of the underground waters could fall by up to $74 \%$ [51]. The scarcity of water resources as a consequence of the effects of climate change place the survival of the agricultural sector at risk, and, therefore, jeopardize the capacity to feed the population. For example, in Mexico, it is estimated that wheat production, which currently amounts to around 3.3 million tonnes, will decrease as a result of climate change [52].

The blue cluster refers to the quality of the water since the spread of certain anthropogenic activities causes the pollution of water resources. This can generate problems in the supply of water fit for human consumption and for agricultural irrigation. De Oca et al. [53] find that the changes in the physical and chemical composition derived from human actions and the changes in the uses of the land have given rise to a reduction in the essential nutrients of the water, which can have an impact on the health of the consumers. In terms of agriculture, Saldaña-Robles et al. [54] conclude that irrigation with water contaminated with arsenic leads to an accumulation of this substance in the soil and its concentration increases in the crops, affecting their growth and yields.

The yellow cluster includes studies focused on the use of remote sensors and satellite images to estimate the yields and water consumption of the crops. For example, these technologies are used to calculate the evapotranspiration of forage maize crops, which enables a more efficient planning of the use of water resources, particularly in arid and semi-arid areas where the water is a limiting factor for agricultural production [55]. Reyes-González et al. [56] develop evapotranspiration maps based on remote sensing multi-spectral vegetation indexes to quantify the water consumption of crops, according to their growth phase. López-Hernández et al. [57] show that the determination of productivity through evapotranspiration can help increase the yields of the crops, as it enables the application of irrigation efficiently in accordance with their needs. Palacios-Vélez et al. [58] used satellite images to estimate the Normalized Difference Vegetation Index (NDVI) and evapotranspiration with the objective of conducting an anticipated estimate of the yield of the wheat crop.

The purple cluster examines the research on the effects that the changes in the land uses and pollution can generate on the biodiversity and conservation of natural spaces and water bodies. The loss of pastures due to the expansion of irrigated crop land is putting the survival of many species at risk as it has transformed their habitat [59]. Andrade-Herrera et al. [60] conclude that the intensification of the agricultural activity and the greater use of pesticides have led to a loss of biodiversity as a result of soil pollution. Vanderplank et al. [61] find that the intrusion of sea water in the aquifers as a result of unsustainable extraction, principally for agricultural irrigation, has had indirect effects on the adjacent ecosystems, leading to the loss of more than 20 native plants in the valley of San Quintín.

The light blue cluster studies erosion, which is one of the main causes of the degradation of the soil and depends on many factors, such as the type of land and soil, the land use, or the climate [62]. Silva-García et al. [63] carried out a study to determine the loss of soil as a consequence of water erosion in the Lake Chapala basin, concluding that it was produced mainly in the seasonal crops and that the organic material suffers the greatest losses. Meanwhile, López-Santos et al. [64] found that the implementation of actions to control soil erosion, such as correct rainwater management or the incorporation of organic material, is still limited among farmers.

The brown cluster shows a research line based on two crops that are fundamental in the Mexican diet: maize (zea mays) and wheat (Triticum aestivum) [15]. In this research field, certain agronomic 
practices are studied, which can improve the efficiency of the use of water and reduce water pollution. Paquini-Rodríguez et al. [65] conducted a study with varieties of wheat in different scenarios and found that using a lower amount of water could obtain the same yields. Honsdorf et al. [66] carried out a study with wheat in different agronomic environments, conventional tillage, and permanent raised beds in order to determine the importance of tillage in crops. Rangel-Fajardo et al. [67] analysed 25 varieties of maize with the objective of identifying their tolerance to water stress during germination. Grahmann et al. [68] found that it is necessary to promote practices that reduce nitrate pollution since the results of their study revealed that $19 \%$ of the nitrate applied in a wheat crop and $34 \%$ in a maize crop was lost by leaching.

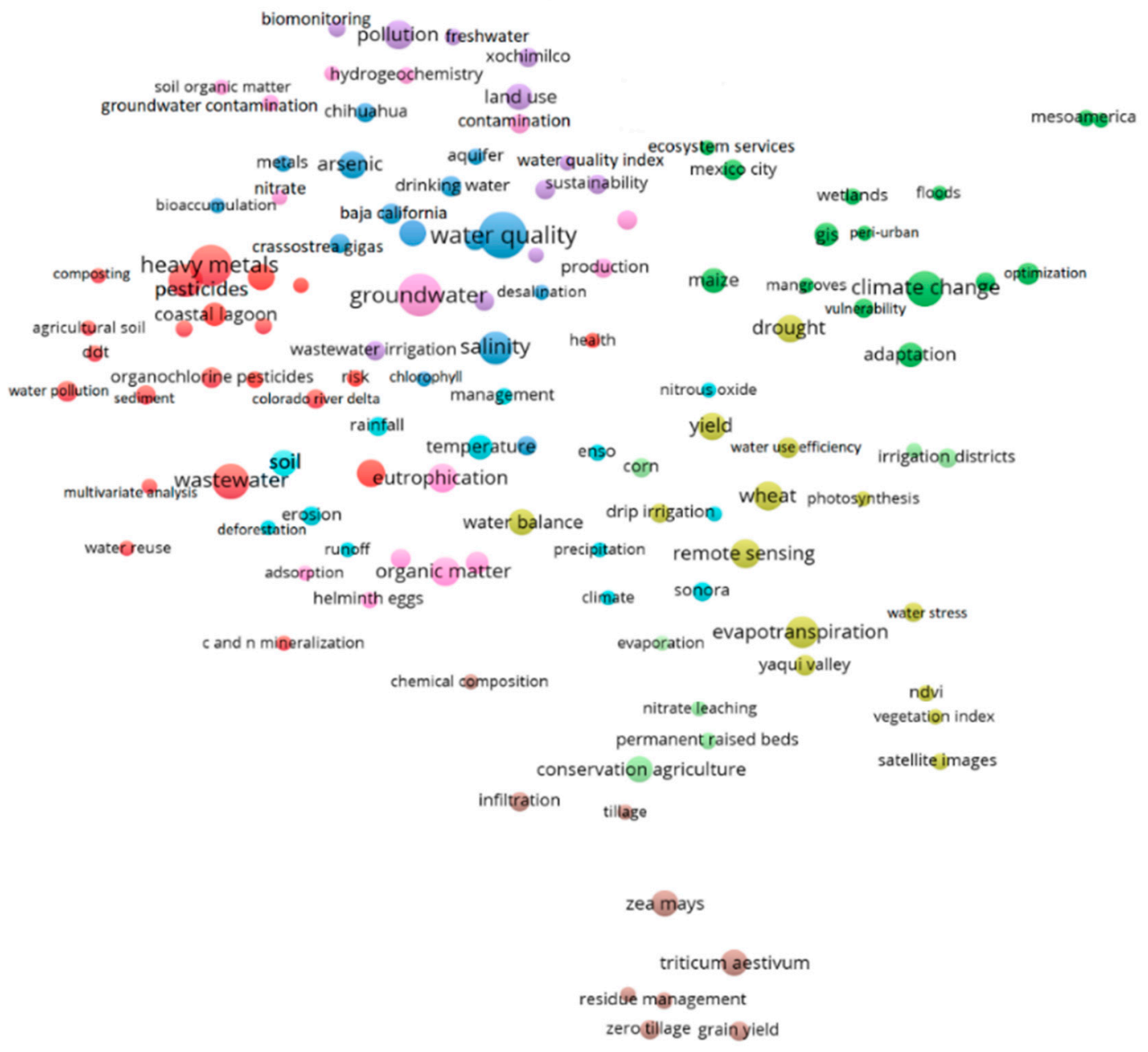

Figure 2. Trends in main keywords related to agricultural water management in Mexico (AWMM) research.

The pink cluster studies underground waters. A large part of the Mexican territory is arid or semi-arid, which means that many areas depend largely on underground water sources that are overexploited. Therefore, it is necessary to carry out actions that allow this situation to be controlled and reversed. For example, Saíz-Rodríguez et al. [69] conducted a study to identify possible locations of artificial recharging of the aquifers in the Valley of Guadalupe (Baja Califormia) while González-Trinidad et al. [70] did the same for the State of Zacatecas. On the other hand, with respect to agricultural activity, incorporating conservation practices and increasing the organic material of the soil can favour the infiltration of rainwater and increase the productivity of the soil, reducing the water needs of the crops [71]. Furthermore, the quality of the underground waters is also being affected by salinisation and pollution due to the use of waste water for agricultural irrigation and 
fertilizers [72]. To do this, it is necessary to design a plan for the use of the aquifers and create action plans that enable the reversal of the salinisation processes to which the aquifers are subjected and, therefore, avoid situations of collapse over the long term [73].

The light green cluster refers to conservation agriculture, which comprises a series of techniques such as minimum tillage, the permanent cover of the soil, and the diversification of the crops, which enable a more efficient use of the natural resources [74]. The application of conservation agriculture together with the efficient management of fertilizers can increase the yields and quality of the production of the crops [75]. Fuentes et al. [76] carried out a study on the maize crop and concluded that the application of conservation agriculture can increase the carbon content of the soil and reduce $\mathrm{CO}_{2}$ emissions. Therefore, conservation agriculture can also favour a better control of plagues, as it improves the quality and reduces the erosion of the soil, creating an ideal habitat for organisms [77].

If we analyse the research on SAWMM, we find four differentiated clusters (Figure 3) with three focused on the fields of sustainability and a fourth based on a more technical perspective of the research.

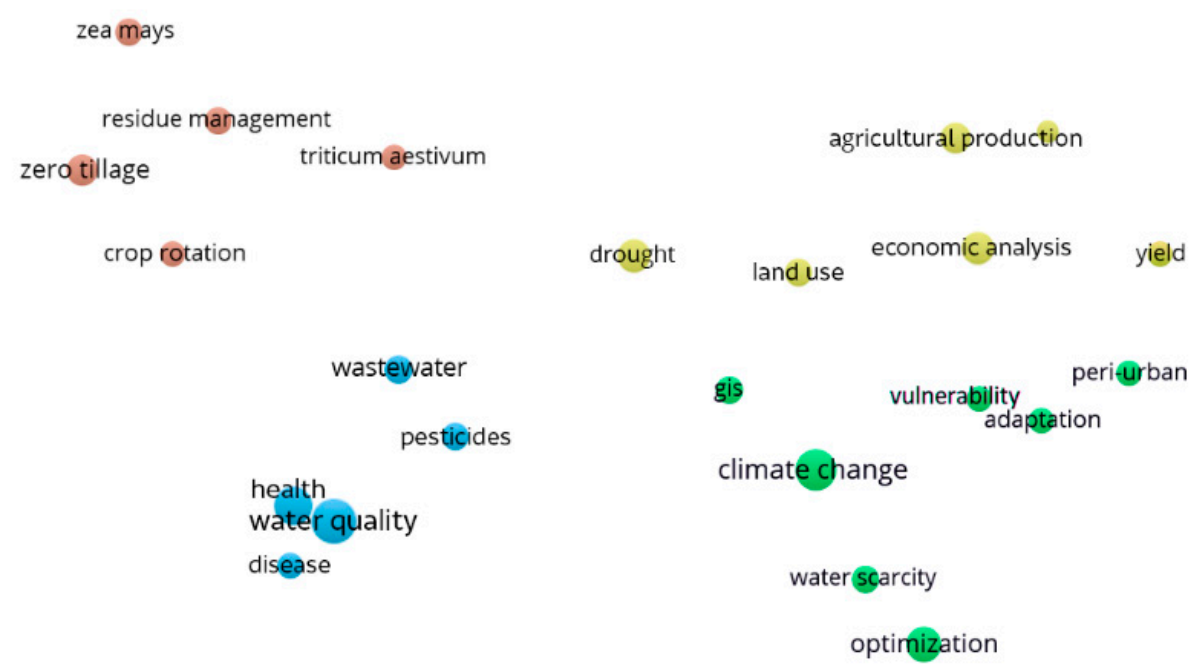

Figure 3. Trends in main keywords related to sustainable agricultural water management in Mexico (SAWMM) research.

The green cluster refers to the environmental dimension of sustainability. It is focused on the research of climate change effects on the availability and management of water resources. This confirms that the environmental perspective of sustainability receives more attention than the rest of the dimensions. In this respect, farmers must take into account the climate variations as part of their production system in order to guarantee the survival of their economic activity and food security [78]. Furthermore, it will also be necessary to identify and study the agricultural areas most prone to variations in order to be able to design specific adaptation plans that minimise their vulnerability to climate change [79].

The blue cluster studies the social dimension, particularly with respect to health. The changes in the uses of the land and the spread of certain anthropogenic practices have led to the contamination of natural resources, which can affect the quality of life and the health of people. The presence of emerging contaminants (faecal sterols, alcaphenols, and pesticides) has been detected in wells in agricultural and urban areas [80]. Contreras et al. [81] carried out a study that compared the incidence of diarrhoeal diseases in children under the age of five in areas that use untreated waste water for irrigation and in which well water is used, concluding that diarrhoea is more frequent in the cases where waste water is used. The accumulation of heavy metals in the soil can put public health at risk since these elements concentrate in the water sources and are absorbed by plants, affecting the quality and security of food [82]. 
The yellow cluster focuses on the economic dimension, as the increase in demand for water and the possible effects derived from climate change can endanger the survival of agriculture [83]. For example, Bautista-Capetillo et al. [84] found that droughts led to losses for the region of Zacatecas with a value of 478 million dollars in a period of 10 years. Granados et al. [85] conducted a study in Guanajuato in which they concluded that the variability of rainfall has given rise to a loss in the productivity of maize and bean crops, which has reduced the revenue and quality of life of the area.

The brown cluster focuses on the study of the most ideal agronomic practices for maize and wheat crops in order to improve production and efficiency in water use to guarantee the sustainability of these crops.

\section{Conclusions}

The objective of this article is to analyse the dynamics of the research on the use of water in agriculture in Mexico and especially its sustainable management. To achieve it, a bibliometric analysis has been carried out on a sample of 1490 articles in the research on AWMM and 436 articles in the case of the research on SAWMM. For each of the lines of research, a productivity analysis has been developed based on the number of articles, the journals, the subject categories, the authors, affiliation, and collaboration relations. The principal topics developed in each of them have also been analysed according to the keywords used.

The results reveal that both lines of research have gained importance in recent years. Although research focusing on the use of water in agriculture in Mexico with a focus on sustainability is still in its infancy, it has become a priority field. This result is consistent with the trend observed on a global level in research in this field, particularly related to the fulfilment of some of the sustainable development objectives of the United Nations. In both cases, the principal subject categories are Environmental Sciences, Agricultural and Biological Sciences, and Earth and Planetary Sciences. This enables us to affirm that, in both cases, there is a predominance of research from a technical and environmental perspective. In the case of the research on SAWMM, the social and economic dimensions of sustainability received greater attention than in the case of the research on AWMM. However, it is necessary to promote research from these two approaches and also all three dimensions of sustainability together.

The analysis of the collaboration networks established by Mexico has enabled us to determine that the number of studies carried out through an international collaboration is higher in the case of research on SAWMM than in the general research on AWMM. In this way, we can see that, similarly to other fields of study, sustainability is not only more multidisciplinary, but it is studied to a greater extent through international collaboration between institutions.

The analysis of keywords reveals nine clusters in the overall subject, focused on topics such as the pollution of water bodies, climate change, the quality of water, the application of technology in order to make a more efficient use of water, biodiversity, erosion, agronomic practices that reduce water consumption, underground water sources, and conservation agriculture. With regard to research on SAWMM, three clusters have been found focused on the three dimensions of sustainability and a fourth analysing more technical aspects of agriculture. The topics on climate change and the technical aspects to improve water efficiency are common in both lines of research.

Author Contributions: The four authors have equally contributed to this paper. All authors have read and agreed to the published version of the manuscript.

Funding: This research received no external funding.

Acknowledgments: This work was partially supported by the Spanish Ministry of Economy and Competitiveness and the European Regional Development Fund by means of the research project ECO2017-82347-P.

Conflicts of Interest: The authors declare no conflict of interest. 


\section{References}

1. Fróna, D.; Szenderák, J.; Rákos, M.H. The Challenge of Feeding the World. Sustainability 2019, 11, 5816. [CrossRef]

2. Oberle, B.; Bringezu, S.; Hatfield-Dodds, S.; Hellweg, S.; Schandl, H.; Clement, J. Global Resources Outlook 2019: Natural Resources for the Future We Want. Available online: http://pure.iiasa.ac.at/id/eprint/15879/1/ unep_252_global_resource_outlook_2019_web.pdf (accessed on 27 July 2020).

3. Ceratti, M. Dos Planetas Más Para Poder Vivir en Este. Available online: https://www.bancomundial.org/es/ news/feature/2016/08/09/objetivo-desarrollo-sostenible-ods-12-consumo (accessed on 27 July 2020).

4. Aznar-Sánchez, J.A.; Piquer-Rodríguez, M.; Velasco-Muñoz, J.F.; Manzano-Agugliaro, F. Worldwide research trends on sustainable land use in agriculture. Land Use Policy 2019, 87, 104069. [CrossRef]

5. Food and Agriculture Organization of the United Nations. High Level Expert Forum-How to Feed the World in 2050; Office of the Director, Agricultural Development Economics Division: Rome, Italy, 2009.

6. Baguma, D.; Loiskandl, W. Rainwater harvesting technologies and practises in rural Uganda: A case study. Mitig. Adapt. Strat. Glob. Chang. 2010, 15, 355-369. [CrossRef]

7. Dias, C.S.L.; Rodrigues, R.G.; Ferreira, J.J. What's new in the research on agricultural entrepreneurship? J. Rural. Stud. 2019, 65, 99-115. [CrossRef]

8. Foley, J.A.; Ramankutty, N.; Brauman, K.A.; Cassidy, E.S.; Gerber, J.S.; Johnston, M.; Mueller, N.D.; O'Connell, C.; Ray, D.K.; West, P.C.; et al. Solutions for a cultivated planet. Nature 2011, 478, 337-342. [CrossRef] [PubMed]

9. Velasco-Muñoz, J.F.; Aznar-Sánchez, J.A.; Belmonte-Ureña, L.J.; López-Serrano, M.J. Advances in Water Use Efficiency in Agriculture: A Bibliometric Analysis. Water 2018, 10, 377. [CrossRef]

10. Cunningham, S.A.; Attwood, S.J.; Bawa, K.S.; Benton, T.G.; Broadhurst, L.M.; Didham, R.K.; McIntyre, S.; Perfecto, I.; Samways, M.J.; Tscharntke, T.; et al. To close the yield-gap while saving biodiversity will require multiple locally relevant strategies. Agric. Ecosyst. Environ. 2013, 173, 20-27. [CrossRef]

11. Mancosu, N.; Snyder, R.L.; Kyriakakis, G.; Spano, D. Water Scarcity and Future Challenges for Food Production. Water 2015, 7, 975-992. [CrossRef]

12. FAO (Food and Agricultural Organization). El sistema alimentario en México-Oportunidades Para el Campo Mexicano en la Agenda 2030 de Desarrollo Sostenible; FAO: Ciudad de México, Mexico, 2019. Available online: http://www.fao.org/3/CA2910ES/ca2910es.pdf (accessed on 27 July 2020).

13. SIAP (Food, Agricultural and Fisheries Information Service). 2019 Food \& Agriculture Overview; SIAP: Mexico City, Mexico, 2019. Available online: https://nube.siap.gob.mx/gobmx_publicaciones_siap/pag/2019/ Agricultural-Atlas-2019 (accessed on 27 July 2020).

14. WTO (World Trade Organization). World Trade Statistical Review 2019. Available online: https://www.wto. org/english/res_e/statis_e/wts2019_e/wts19_toc_e.htm (accessed on 27 July 2020).

15. Sosa-Baldivia, A.; Ruíz-Ibarra, G. Food availability in Mexico: An analysis of agricultural production over the last 35 years and its projection for 2050. Pap. Poblac. 2017, 23, 207-230.

16. The World Bank. 2020. Available online: https://data.worldbank.org/indicator/SL.AGR.EMPL.ZS?end= 2019\&locations=MX\&start=1991 (accessed on 29 July 2020).

17. Riojas, C. La naturaleza de las articulaciones regionales en México a través del tiempo. Amerika 2011, 4. [CrossRef]

18. Conagua (Comisión Nacional del Agua). Estadisticas del Agua en México; Edición 2018; Conagua: Ciudad de México, México, 2018. Available online: http://sina.conagua.gob.mx/publicaciones/EAM_2018.pdf (accessed on 29 July 2020).

19. Secretaria de Medio Ambiente y Recursos Naturales (Semarnat); Comisión Nacional del Agua (Conagua). Programa Nacional Hídrico 2019-2014. 2019. Available online: http://187.191.71.192/portales/resumen/48732 (accessed on 29 July 2020).

20. Gómez-Merino, F.C.; Hernández-Anguiano, A.M. El Contexto del Sector Agroalimentario en México. In Lineas Prioritarias de Investigación. Informe de Gestión 2009-2011; Hernández-Anguiano, A.M., Gómez-Merino, F.C., Pérez-Hernández, L.M., Villanueva-Jiménez, J.A., Eds.; Colegio de Postgraduados: Estado de México, México, 2013; ISBN 978-607-715-135-7.

21. Delgado-Carranza, C.; Bautista, F.; Ihl, T.J.; Palma-López, D. Duración del periodo de lluvias y aptitud de tierras para la agricultura de temporal. Ecosistemas Recur. Agropecu. 2017, 4, 485-497. [CrossRef] 
22. ENA (Encuesta Nacional Agropecuaria). 2017. Available online: https://www.inegi.org.mx/programas/ena/ 2017/ (accessed on 29 July 2020).

23. Romero, A.A.; Rivas, A.I.M.; Díaz, J.D.G.; Mendoza, M.; Ángel, P.; Salas, E.N.N.; Blanco, J.L.; Álvarez, A.C.C. Crop yield simulations in Mexican agriculture for climate change adaptation. Atmósfera 2020, 33, $215-231$. [CrossRef]

24. García-Hernández, J.; Leyva-Morales, J.B.; Martínez-Rodríguez, I.E.; Hernández-Ochoa, M.I.; Aldana-Madrid, M.L.; Rojas-García, A.E.; Betancourt-Lozano, M.; Pérez-Herrera, N.E.; Perera-Ríos, J.H. Estado actual de la investigación sobre plaguicidas en México. Rev. Int. Contam. Ambient. 2018, 34, $29-60$. [CrossRef]

25. Bonilla-Moheno, M.; Redo, D.J.; Aide, T.M.; Clark, M.L.; Grau, H.R. Vegetation change and land tenure in Mexico: A country-wide analysis. Land Use Policy 2013, 30, 355-364. [CrossRef]

26. Komiyama, H.; Takeuchi, K. Sustainability science: Building a new discipline. Sustain. Sci. 2006, 1, 1-6. [CrossRef]

27. Yarime, M.; Takeda, Y.; Kajikawa, Y. Towards institutional analysis of sustainability science: A quantitative examination of the patterns of research collaboration. Sustain. Sci. 2009, 5, 115-125. [CrossRef]

28. Velasco-Muñoz, J.F.; Aznar-Sánchez, J.A.; Batlles-Delafuente, A.; Fidelibus, M.D. Sustainable Irrigation in Agriculture: An Analysis of Global Research. Water 2019, 11, 1758. [CrossRef]

29. Garfield, E.; Sher, I.H. New factors in the evaluation of scientific literature through citation indexing. Am. Doc. 1963, 14, 195-201. [CrossRef]

30. Huang, L.; Zhang, Y.; Guo, Y.; Zhu, D.; Porter, A.L. Four dimensional Science and Technology planning: A new approach based on bibliometrics and technology roadmapping. Technol. Forecast. Soc. Chang. 2014, 81, 39-48. [CrossRef]

31. Aznar-Sánchez, J.A.; García-Gómez, J.J.; Velasco-Muñoz, J.F.; Carretero-Gómez, A. Mining Waste and Its Sustainable Management: Advances in Worldwide Research. Minerals 2018, 8, 284. [CrossRef]

32. Aznar-Sánchez, J.A.; Belmonte-Ureña, L.J.; López-Serrano, M.J.; Velasco-Muñoz, J.F. Forest Ecosystem Services: An Analysis of Worldwide Research. Forests 2018, 9, 453. [CrossRef]

33. Albort-Morant, G.; Henseler, J.; Leal-Millán, A.; Carrión, G.A.C. Mapping the Field: A Bibliometric Analysis of Green Innovation. Sustainability 2017, 9, 1011. [CrossRef]

34. Opejin, A.K.; Aggarwal, R.M.; White, D.D.; Jones, J.L.; Maciejewski, R.; Mascaro, G.; Sarjoughian, H.S. A Bibliometric Analysis of Food-Energy-Water Nexus Literature. Sustainability 2020, 12, 1112. [CrossRef]

35. Durieux, V.; Gevenois, P.A. Bibliometric Indicators: Quality Measurements of Scientific Publication. Radiology 2010, 255, 342-351. [CrossRef] [PubMed]

36. Robinson, D.K.R.; Huang, L.; Guo, Y.; Porter, A.L. Forecasting Innovation Pathways (FIP) for new and emerging science and technologies. Technol. Forecast. Soc. Chang. 2013, 80, 267-285. [CrossRef]

37. Figueroa-Rodríguez, K.A.; Álvarez-Ávila, M.D.C.; Castillo, F.H.; Rindermann, R.S.; Sandoval, B.F. Farmers' Market Actors, Dynamics, and Attributes: A Bibliometric Study. Sustainability 2019, 11, 745. [CrossRef]

38. Kumar, A.; Mallick, S.; Swarnakar, P. Mapping Scientific Collaboration: A Bibliometric Study of Rice Crop Research in India. J. Sci. Res. 2020, 9, 29-39. [CrossRef]

39. Gavel, Y.; Iselid, L. Web of Science and Scopus: A journal title overlap study. Online Inf. Rev. 2008, 32, 8-21. [CrossRef]

40. Aznar-Sánchez, J.A.; Belmonte-Ureña, L.J.; Velasco-Muñoz, J.F.; Manzano-Agugliaro, F. Economic analysis of sustainable water use: A review of worldwide research. J. Clean. Prod. 2018, 198, 1120-1132. [CrossRef]

41. Ngwenya, S.; Boshoff, N. Participation of 'international national organisations' in Africa's research: A bibliometric study of agriculture and health in Zimbabwe. Scientometrics 2020, 124, 533-553. [CrossRef]

42. Velasco-Muñoz, J.F.; Aznar-Sánchez, J.A.; Belmonte-Ureña, L.J.; Román-Sánchez, I.M. Sustainable Water Use in Agriculture: A Review of Worldwide Research. Sustainability 2018, 10, 1084. [CrossRef]

43. Alonso, S.; Cabrerizo, F.J.; Herrera-Viedma, E.; Herrera, F. h-Index: A review focused in its variants, computation and standardization for different scientific fields. J. Informetr. 2009, 3, 273-289. [CrossRef]

44. Falagas, M.E.; Kouranos, V.D.; Arencibia-Jorge, R.; Karageorgopoulos, D.E. Comparison of SCImago journal rank indicator with journal impact factor. FASEB J. 2008, 22, 2623-2628. [CrossRef] [PubMed]

45. Aznar-Sánchez, J.A.; Velasco-Muñoz, J.F.; Belmonte-Ureña, L.J.; Manzano-Agugliaro, F. Innovation and technology for sustainable mining activity: A worldwide research assessment. J. Clean. Prod. 2019, 221, 38-54. [CrossRef] 
46. Robledo-Zacarías, V.H.; Velázquez-Machuca, M.A.; Montañez-Soto, J.L.; Pimentel-Equihua, J.L.; Vallejo-Cardona, A.A.; López-Calvillo, M.D.; Venegas-González, J. Hydrochemistry and emerging contaminants in industrial urban wastewater in Morelia, Michoacán, Mexico. Rev. Int. Contam. Ambie. 2017, 33, 221-235. [CrossRef]

47. Gilabert-Alarcón, C.; Salgado-Méndez, S.O.; Daesslé, L.W.; Mendoza-Espinosa, L.G.; Villada-Canela, M. Regulatory Challenges for the Use of Reclaimed Water in Mexico: A Case Study in Baja California. Water 2018, 10, 1432. [CrossRef]

48. Castresana, G.P.; Flores, V.T.; Reyes, L.L.; Aldana, F.H.; Vega, R.C.; Perales, J.L.M.; Suastegui, W.A.G.; Diaz, A.; Silva, A.H. Atoyac River Pollution in the Metropolitan Area of Puebla, México. Water 2018, 10, 267. [CrossRef]

49. Rodríguez-Aguilar, B.A.; Martínez-Rivera, L.M.; Peregrina-Lucano, A.A.; Ortiz-Arrona, C.I.; Cárdenas-Hernández, O.G. Analysis of pesticide residues in the surface water of the Ayuquila-Armeria River watershed, Mexico. Terra Latinoam. 2019, 37, 151-161. [CrossRef]

50. Hernández-Bedolla, J.; Solera, A.; Paredes-Arquiola, J.; Pedro-Monzonís, M.; Andreu, J.; Sánchez-Quispe, S.T. The Assessment of Sustainability Indexes and Climate Change Impacts on Integrated Water Resource Management. Water 2017, 9, 213. [CrossRef]

51. Molina-Navarro, E.; Hallack-Alegría, M.; Martínez-Pérez, S.; Ramírez-Hernández, J.; Mungaray-Moctezuma, A.; Sastre-Merlín, A. Hydrological modeling and climate change impacts in an agricultural semiarid region. Case study: Guadalupe River basin, Mexico. Agric. Water Manag. 2016, 175, 29-42. [CrossRef]

52. Hernandez-Ochoa, I.M.; Pequeno, D.N.L.; Reynolds, M.; Babar, M.A.; Sonder, K.; Milan, A.M.; Hoogenboom, G.; Robertson, R.; Gerber, S.; Rowland, D.L.; et al. Adapting irrigated and rainfed wheat to climate change in semi-arid environments: Management, breeding options and land use change. Eur. J. Agron. 2019, 109, 125915. [CrossRef]

53. De Oca, R.M.G.F.; Ramos-Leal, J.A.; Solache-Ríos, M.J.; Martínez-Miranda, V.; Fuentes-Rivas, R.M. Modification of the Relative Abundance of Constituents Dissolved in Drinking Water Caused by Organic Pollution: A Case of the Toluca Valley, Mexico. Water Air Soil Pollut. 2019, 230, 171. [CrossRef]

54. Saldaña-Robles, A.; Abraham-Juárez, M.R.; Saldaña-Robles, A.L.; Saldaña-Robles, N.; Ozuna, C.; Gutiérrez-Chávez, A.J. The Negative Effect of Arsenic in Agriculture: Irrigation Water, Soil And Crops, State of the Art. Appl. Ecol. Environ. Res. 2018, 16, 1533-1551. [CrossRef]

55. Reyes-González, A.; Reta-Sánchez, D.G.; Sánchez-Duarte, J.I.; Ochoa-Martínez, E.; Rodríguez-Hernández, K.; Preciado-Rangel, P. Estimation of evapotranspiration of forage corn supported with remote sensing and in situ measurements. Terra Latinoam. 2019, 37, 279-290. [CrossRef]

56. Reyes-González, A.; Kjaersgaard, J.; Trooien, T.; Hay, C.; Ahiablame, L. Estimation of Crop Evapotranspiration Using Satellite Remote Sensing-Based Vegetation Index. Adv. Meteorol. 2018, 2018, 1-12. [CrossRef]

57. López-Hernández, M.; Arteaga-Ramírez, R.; Ruiz-García, A.; Vázquez-Peña, M.A.; López-Resano, J.I. Productividad del agua normalizada para el cultivo de maíz (Zea mays) en Chapingo, México. Agrociencia 2019, 53, 811-820.

58. Palacios-Vélez, E.; Palacios-Sánchez, L.; Espinosa-Espinosa, J.L. Early estimation of the wheat crop yield in irrigation district 038, Río Mayo, Sonora, México/Estimación temprana del rendimiento de la cosecha de trigo en el distrito de riego 038, Río Mayo, Sonora, México. Tecnol. Cienc. Agua 2019, 10, 225-240. [CrossRef]

59. Pool, D.B.; Panjabi, A.O.; Macías-Duarte, A.; Solhjem, D.M. Rapid expansion of croplands in Chihuahua, Mexico threatens declining North American grassland bird species. Biol. Conserv. 2014, 170, $274-281$. [CrossRef]

60. Andrade-Herrera, M.; Escalona-Segura, G.; González-Jáuregui, M.; Reyna-Hurtado, R.A.; Vargas-Contreras, J.A.; Osten, J.R.-V. Presence of Pesticides and Toxicity Assessment of Agricultural Soils in the Quintana Roo Mayan Zone, Mexico Using Biomarkers in Earthworms (Eisenia fetida). Water Air Soil Pollut. 2019, 230, 59. [CrossRef]

61. Vanderplank, S.; Ezcurra, E.; Delgadillo, J.; Felger, R.; McDade, L.A. Conservation challenges in a threatened hotspot: Agriculture and plant biodiversity losses in Baja California, Mexico. Biodivers. Conserv. 2014, 23, 2173-2182. [CrossRef]

62. Estrada-Herrera, I.R.; Hidalgo-Moreno, C.; Guzmán-Plazola, R.; Almaraz Suárez, J.J.; Navarro-Garza, H.; Etchevers-Barra, J.D. Soil quality indicators to evaluate soil fertility. Agrociencia 2017, 51, 813-831. 
63. Silva-García, J.T.; Cruz-Cárdenas, G.; Ochoa-Estrada, S.; Estrada-Godoy, F.; Nava-Velázquez, J.; Álvarez-Bernal, D. Loss of soil from water erosion in the basin Chapala Lake, Michoacan, Mexico. Tecnol. Cienc. Agua 2017, 8, 117-128. [CrossRef]

64. López-Santos, A.; Bueno-Hurtado, P.; Arreola-ávila, J.G.; Emmanuel Pérez-Salinas, J. Conservation activities of soils identified through indices kappa indices in northeast of Durango, Mexico. Agrociencia 2017, 51, 591-605.

65. Paquini-Rodríguez, S.L.; Benítez-Riquelme, I.; Villaseñor-Mir, H.E.; Muñoz-Orozco, A.; Vaquera-Huerta, H. Gains in yield and its components under normal and limited irrigation of Mexican wheat cultivars. Rev. Fitotec. Mex. 2016, 39, 367-378.

66. Honsdorf, N.; Mulvaney, M.J.; Singh, R.P.; Ammar, K.; Burgueño, J.; Govaerts, B.; Verhulst, N. Genotype by tillage interaction and performance progress for bread and durum wheat genotypes on irrigated raised beds. Field Crop. Res. 2018, 216, 42-52. [CrossRef]

67. Rangel-Fajardo, M.A.; Gómez-Montiel, N.; Tucuch-Haas, J.I.; De la Cruz Basto-Barbudo, D.; Villalobos-González, A.; Burgos-Díaz, J.A. Polyethylene glicol 8000 to identify corn tolerant to water stress during germination. Agron. Mesoam. 2019, 30, 255-266. [CrossRef]

68. Grahmann, K.; Verhulst, N.; Palomino, L.M.; Bischoff, W.-A.; Govaerts, B.; Buerkert, A. Ion exchange resin samplers to estimate nitrate leaching from a furrow irrigated wheat-maize cropping system under different tillage-straw systems. Soil Tillage Res. 2018, 175, 91-100. [CrossRef]

69. Saiz-Rodríguez, J.A.; Banda, M.A.L.; Salazar-Briones, C.; Ruiz-Gibert, J.M.; Mungaray-Moctezuma, A. Allocation of Groundwater Recharge Zones in a Rural and Semi-Arid Region for Sustainable Water Management: Case Study in Guadalupe Valley, Mexico. Water 2019, 11, 1586. [CrossRef]

70. González-Trinidad, J. Dynamics of Land Cover Changes and Delineation of Groundwater Recharge Potential Sites in the Aguanaval Aquifer, Zacatecas, Mexico. Appl. Ecol. Environ. Res. 2017, 15, 387-402. [CrossRef]

71. Aguilar-García, R.; Ortega-Guerrero, M.A. Analysis of the water dynamics in the unsaturated zone, in a soil subject to conservation practices: Implications for aquifer management and adaptation to climatic change. Rev. Mex. Cienc. Geol. 2017, 34, 91-104.

72. Celestino, A.E.M.; Ramos-Leal, J.; Cruz, D.A.M.; Tuxpan, J.; Bashulto, J.D.L.; Ramírez, J.M. Identification of the Hydrogeochemical Processes and Assessment of Groundwater Quality, Using Multivariate Statistical Approaches and Water Quality Index in a Wastewater Irrigated Region. Water 2019, 11, 1702. [CrossRef]

73. Mahlknecht, J.; Merchán, D.; Rosner, M.; Meixner, A.; Ledesma-Ruiz, R. Assessing seawater intrusion in an arid coastal aquifer under high anthropogenic influence using major constituents, $\mathrm{Sr}$ and B isotopes in groundwater. Sci. Total. Environ. 2017, 587-588, 282-295. [CrossRef] [PubMed]

74. Fonteyne, S.; Gamiño, M.-A.M.; Tejeda, A.S.; Verhulst, N. Conservation Agriculture Improves Long-term Yield and Soil Quality in Irrigated Maize-oats Rotation. Agronomy 2019, 9, 845. [CrossRef]

75. Santillano-Cázares, J.; Núñez-Ramírez, F.; Ruíz-Alvarado, C.; Cárdenas-Castañeda, M.E.; Ortiz-Monasterio, J.I. Assessment of Fertilizer Management Strategies Aiming to Increase Nitrogen Use Efficiency of Wheat Grown Under Conservation Agriculture. Agronomy 2018, 8, 304. [CrossRef]

76. Fuentes, M.; Hidalgo, C.; Etchevers, J.; De León, F.; Guerrero, A.; Dendooven, L.; Verhulst, N.; Govaerts, B. Conservation agriculture, increased organic carbon in the top-soil macro-aggregates and reduced soil $\mathrm{CO} 2$ emissions. Plant Soil 2012, 355, 183-197. [CrossRef]

77. Rivers, A.; Barbercheck, M.; Govaerts, B.; Verhulst, N. Conservation agriculture affects arthropod community composition in a rainfed maize-Wheat system in central Mexico. Appl. Soil Ecol. 2016, 100, 81-90. [CrossRef]

78. Paredes-Tavares, J.; Gómez-Albores, M.A.; Mastachi-Loza, C.A.; Delgado, C.D.; Becerril-Piña, R.; Martínez-Valdés, H.; Bâ, K.M. Impacts of Climate Change on the Irrigation Districts of the Rio Bravo Basin. Water 2018, 10, 258. [CrossRef]

79. Ahumada-Cervantes, R.; Angulo, G.V.; Rodríguez-Gallegos, H.B.; Flores-Tavizón, E.; Felix-Gastelum, R.; Romero-Gonzalez, J.; Granados-Olivas, A. An indicator tool for assessing local vulnerability to climate change in the Mexican agricultural sector. Mitig. Adapt. Strat. Glob. Chang. 2017, 22, 137-152. [CrossRef]

80. González-Acevedo, Z.I.; Zarate, M.A.G.; Flores-Lugo, I.P. Emerging contaminants and nutrients in a saline aquifer of a complex environment. Environ. Pollut. 2019, 244, 885-897. [CrossRef] 
81. Contreras, J.D.; Meza, R.; Siebe, C.; Rodríguez-Dozal, S.; López-Vidal, Y.; Castillo-Rojas, G.; Amieva, R.I.; Solano-Gálvez, S.G.; Mazari-Hiriart, M.; Silva-Magaña, M.A.; et al. Health risks from exposure to untreated wastewater used for irrigation in the Mezquital Valley, Mexico: A 25-year update. Water Res. 2017, 123, 834-850. [CrossRef]

82. Castro-González, N.P.; Calderón-Sánchez, F.; Moreno-Rojas, R.; Tamariz-Flores, J.V.; Reyes-Cervantes, E. Heavy metals pollution level in wastewater and soils in the alto balsas sub-basin in Tlaxcala and Puebla, Mexico. Rev. Int. Contam. Ambient. 2019, 35, 335-348. [CrossRef]

83. Duchin, F.; López-Morales, C. Do Water-Rich Regions Have a Comparative Advantage in Food Production? Improving the Representation of Water for Agriculture in Economic Models. Econ. Syst. Res. 2012, 24, 371-389. [CrossRef]

84. Bautista-Capetillo, C.; Carrillo, B.; Picazo, G.; Júnez-Ferreira, H. Drought Assessment in Zacatecas, Mexico. Water 2016, 8, 416. [CrossRef]

85. Granados, R.; Soria, J.; Cortina, M. Rainfall variability, rainfed agriculture and degree of human marginality in North Guanajuato, Mexico. Singap. J. Trop. Geogr. 2017, 38, 153-166. [CrossRef]

Publisher's Note: MDPI stays neutral with regard to jurisdictional claims in published maps and institutional affiliations.

(C) 2020 by the authors. Licensee MDPI, Basel, Switzerland. This article is an open access article distributed under the terms and conditions of the Creative Commons Attribution (CC BY) license (http://creativecommons.org/licenses/by/4.0/). 